Matematikai Közlemények

VII. kötet, 2019

doi:10.20312/dim.2019.06

\title{
Elsőrendű differenciálegyenletes modellek
}

\author{
Horváth-Szováti Erika \\ Soproni Egyetem Matematikai Intézet \\ horvath-szovati.erika@uni-sopron.hu
}

\begin{abstract}
ÖSSZEFOGLALÓ. Sok tudományterületen fordulnak elő olyan problémák, amelyek megoldásához differenciálegyenletek használata szükséges. Ennek szemléltetése nem egyszerü, mivel hallgatóink csupán egy-két differenciálegyenlet-típusról tanulnak, csak a legfontosabb integrálási módszereket ismerik, és legtöbbször a differenciálegyenletek felírásához nélkülözhetetlen fizikai, kémiai, stb. ismeretekkel sem rendelkeznek. Az itt összegyüjtött egyszerü modellek rávilágítanak a differenciálegyenletek alkalmazásának módjára és szükségességére.
\end{abstract}

ABSTRACT. These simple practical models highlights the practical application of differential equations. To solve these math problems, students need only a little background knowledge. By these exercises students can see that differential equations are essential in different sciences.

\section{Bevezetés}

A természettudományokban, gazdaságtudományokban, és még sok más területen gyakran fordulnak elő olyan problémák, amelyekkel kapcsolatban a változás és annak üteme kerül a vizsgálat középpontjába, azaz differenciálegyenlettel oldhatók meg. Napjainkban az agrármüszaki felsőoktatásban, illetve a müszaki felsőoktatás nem klasszikus (pl. faipari mérnök, mechatronikai mérnök, stb.) szakjain BSc képzésben legtöbb intézményben a matematika óraszámok csökkenése tapasztalható. Emiatt egyre kevesebb idő jut a differenciálszámítás, integrálszámítás és differenciálegyenletek témakörére. Az integrálási módszerek közül csak a fontosabbakat tanítjuk, és a differenciálegyenletek témakörét is csak érintőlegesen, csupán egykét típus erejéig tárgyaljuk. Az itt bemutatásra kerülő viszonylag egyszerü feladatok differenciálegyenlettel történő megoldása hallgatóink matematikai ismereteivel is lehetséges. A szükséges fizikai, kémiai, és egyéb ismereteket a feladatok szövegében röviden összefoglaltuk. A folyamatot leíró differenciálegyenlet a példában adott, csupán annak értelmezése és megoldása, valamint az esetleges további kérdések megválaszolása a feladat. Az itt összegyüjtött modellek segítségével rávilágíthatunk a differenciálegyenletek alkalmazására, használatuk szükségességére. A feladatokban szereplö ismeretlen függvények különböző jelölései (pl.: $v(t), p(z), T(t)$, stb.) segíthetik a hallgatókat abban, hogy ne csak a szokásos $y(x)$ alakban legyenek képesek a differenciálegyenleteket megoldani, hanem a tudás elsajátításának egy magasabb szintjére lépjenek. 


\section{Elsőrendû́, szétválasztható változójú differenciálegyenlettel megoldható feladatok}

1. Egy $30 \frac{\mathrm{m}}{\mathrm{s}}$ kezdôsebességgel magára hagyott motorcsónak sebessége az indulástól számított 30 másodperc idôpillanatban $15 \frac{\mathrm{m}}{\mathrm{s}}$. Jelöljük $v(t)$-vel a motorcsónak sebesség-idő függvényét. $A$ test sebessége minden idôpillanatban a pillanatnyi sebesség négyzetével arányosan csökken: $-v^{\prime}(t)=k \cdot v^{2}(t)$, ahol $k(\in \mathbb{R})$ arányossági tényezö, neve közegellenállási együttható. Mekkora lesz a csónak sebessége az indulástól számított 60 másodperc múlva?

Megoldás.

A feladatban adott differenciálegyenletből indulunk ki, amely szétválasztható változójú:

$$
\begin{gathered}
-\frac{v(t)}{v^{2}(t)}=k, \\
\int-\frac{v^{\prime}(t)}{v^{2}(t)} d t=\int k d t, \\
\frac{1}{v(t)}=k t+C, \\
v(t)=\frac{1}{k t+C}, \quad k, C \in \mathbb{R} .
\end{gathered}
$$

A kapott függvényben lévő két szabadon választható paraméter ( $k$ és $C$ ) értékét a kezdeti feltételekkel határozzuk meg. Adott volt, hogy a test sebessége a $t=0 \mathrm{~s}$ idópillanatban $30 \frac{\mathrm{m}}{\mathrm{s}}$, és $t=30 \mathrm{~s}$ időpillanatban pedig $15 \frac{\mathrm{m}}{\mathrm{s}}$ :

$$
\begin{gathered}
v(0)=30, \\
v(30)=15 .
\end{gathered}
$$

Ezeket behelyettesítve az általános megoldásba az

$$
\left.\begin{array}{c}
\frac{1}{k \cdot 0+C}=30 \\
\frac{1}{k \cdot 30+C}=15
\end{array}\right\}
$$

egyenletrendszert kapjuk. Az első egyenletből $C=\frac{1}{30}$, ezt beírva a másodikba $k=\frac{1}{900}$ adódik. Tehát a kezdeti feltételeknek megfelelő partikuláris megoldás:

$$
v(t)=\frac{900}{t+30},
$$

amelyből kiszámoljuk a csónak sebességét az indulástól számított 60 másodperc elteltével:

$$
v(60)=\frac{900}{90}=10\left(\frac{m}{s}\right) .
$$


2. Egy $v_{0}=100 \frac{m}{s}$ kezdősebességgel függőlegesen felfelé kilött rakéta sebesség-idő függvényét jelöljük $v(t)$-vel. A sebesség csökkenését minden időpillanatban a rakétára lefelé ható gravitációs gyorsulás ( $g \approx 10 \frac{\mathrm{m}}{\mathrm{s}^{2}}$ ), illetve a közegellenállás okozza, ez utóbbi a rakéta pillanatnyi sebességének négyzetével egyenesen arányos, azaz: $-v^{\prime}(t)=g+k \cdot v^{2}(t)$, ahol a $k(\in \mathbb{R}$ ) arányossági tényező neve közegellenállási együttható. (Feltesszük, hogy a rakéta mozgását akadályozó légellenállás állandó.) A pálya legmagasabb pontján a rakéta sebessége $0 \frac{\mathrm{m}}{\mathrm{s}}$. Határozzuk meg a $v(t)$ függvényt és azt a $T$ időpillanatot, amikor a rakéta eléri pályájának lemagasabb pontját!

Megoldás.

A differenciálegyenlet változóit szétválasztjuk és az integrálást elvégezzük:

$$
\begin{gathered}
\frac{v^{\prime}(t)}{1+\frac{k}{10} v^{2}(t)}=-10, \\
\int \frac{v^{\prime}(t)}{1+\left(\sqrt{\frac{k}{10}} v(t)\right)^{2}} d t=-\int 10 d t, \\
\operatorname{arctg}\left(\sqrt{\frac{k}{10}} v(t)\right)=\sqrt{\frac{k}{10}}(-10 t+C), \quad C \in \mathbb{R} .
\end{gathered}
$$

$\mathrm{A} \sqrt{\frac{k}{10}} \cdot C=C_{2}\left(C_{2} \in \mathbb{R}\right)$ új konstanst bevezetve

$$
\operatorname{arctg}\left(\sqrt{\frac{k}{10}} v(t)\right)=-\sqrt{10 k} \cdot t+C_{2},
$$

ebből a következő sebesség-idő függvényt kapjuk:

$$
v(t)=\sqrt{\frac{10}{k}} \cdot \operatorname{tg}\left(C_{2}-\sqrt{10 k} \cdot t\right), \quad k, C_{2} \in \mathbb{R} .
$$

Adott a feladatban, hogy a rakéta sebessége a $t=0$ másodperc időpillanatban $100 \frac{\mathrm{m}}{\mathrm{s}}$, illetve a keresett $T$ időpillanatban a sebessége $0 \frac{\mathrm{m}}{\mathrm{s}}$. Ezeket visszaírjuk az általános megoldásba:

$$
\left.\begin{array}{c}
\sqrt{\frac{10}{k}} \cdot \operatorname{tg}\left(C_{2}-\sqrt{10 k} \cdot 0\right)=100 \\
\sqrt{\frac{10}{k}} \cdot \operatorname{tg}\left(C_{2}-\sqrt{10 k} \cdot T\right)=0
\end{array}\right\}
$$

Az első egyenletből: $C_{2}=\operatorname{arctg}(\sqrt{1000 k})$, a másodikból: $T=\frac{C_{2}}{\sqrt{10 k}}$. Behelyettesítve $C_{2}-\mathrm{t}$ a $T$ kifejezésébe:

$$
T=\frac{\operatorname{arctg}(\sqrt{1000 k})}{\sqrt{10 k}}
$$


ahol $k(\in \mathbb{R})$ a közegellenállási együttható.

3. Minden vízcsepp a felszínével arányos sebességgel párolog el. Egy közelítőleg gömb alakú vízcsepp átmérője kezdetben $3 \mathrm{~mm}, 20$ másodperc múlva pedig $1 \mathrm{~mm}$. Jelöljük $d(t)$ vel a vízcsepp átmérőjét az idő függvényében. Az átmérő csökkenésének sebessége tehát arányos a gömb felszínével, emiatt az átmérō négyzetével is, azaz: $-d^{\prime}(t)=A \cdot d^{2}(t)$, ahol $A \in \mathbb{R}$ arányossági tényező. Mekkora lesz a vízcsepp átmérője 50 másodperc elteltével?

Megoldás.

A feladatban adott differenciálegyenletből indulunk ki, amely szétválasztható változójú. Megoldásának menete hasonló az előző feladatban leírtakhoz, így nem részletezzük:

$$
\begin{gathered}
-\frac{d^{\prime}(t)}{d^{2}(t)}=A, \\
\vdots \\
d(t)=\frac{1}{A t+C}, A, C \in \mathbb{R} .
\end{gathered}
$$

Az $A$ és $C$ konstansok értékeit a kezdeti feltételekből meghatározzuk. A vízcsepp átméröje a $t=0 \mathrm{~s}$ időpillanatban $3 \mathrm{~mm}, t=20 \mathrm{~s}$ esetén pedig $1 \mathrm{~mm}$, azaz: $d(0)=3, d(20)=1$. Ezeket visszaírva az általános megoldásba egy egyenletrendszert kapunk, melynek megoldása $A=\frac{1}{30}$ és $C=\frac{1}{3}$. A kezdeti feltételeknek megfelelö partikuláris megoldás tehát:

$$
d(t)=\frac{1}{\frac{1}{30} t+\frac{1}{3}}=\frac{30}{t+10}
$$

Ebből kiszámoljuk a vízcsepp átmérőjét 50 másodperc múlva:

$$
d(50)=\frac{30}{60}=0,5(\mathrm{~mm}) .
$$

4. Egy radioaktív anyag bomlását vizsgáljuk. A bomlási folyamat kezdetekor $100 \mathrm{db}$ radioaktív atom volt, az anyag felezési ideje 1 perc. Hány darab sugárzó atom lesz a bomlási folyamat kezdetétől számított másfél perc múlva? Jelöljük $N(t)$-vel a sugárzó (még nem el nem bomlott) atomok számát. Radioaktív bomlás során a radioaktív atomok számának csökkenési sebessége minden időpillanatban arányos a még el nem bomlott atomok számával: $N^{\prime}(t)=-A \cdot N(t)$, ahol $A \in \mathbb{R}$ arányossági tényező.

Megoldás.

A feladatban adott differenciálegyenlet szétválasztható változójú:

$$
\begin{gathered}
\int \frac{N^{\prime}(t)}{N(t)} d t=\int-A d t, \\
\ln |N(t)|=-A t+C, \quad C \in \mathbb{R}, \\
|N(t)|=e^{-A t+C}, \\
N(t)= \pm e^{C} e^{-A t} .
\end{gathered}
$$

$\mathrm{A} \pm e^{C}=C_{2}\left(C_{2} \in \mathbb{R}\right)$ új konstanst bevezetve a következő megoldás adódik: 


$$
N(t)=C_{2} e^{-A t}, \quad C_{2} \in \mathbb{R}
$$

A differenciálegyenlet általános megoldása két szabadon választható paramétert ( $A$ és $\left.C_{2}\right)$ tartalmaz. Ezek értékeit a feladat szövegében lévő kezdeti feltételek segítségével határozzuk meg:

$$
N(0)=100,
$$

illetve a vizsgált anyag felezési ideje 1 perc, azaz 60 másodperc:

$$
N(60)=50 \text {. }
$$

A kezdeti feltételeket behelyettesítve az általános megoldásba a

$$
\left.\begin{array}{l}
C_{2} e^{-A \cdot 0}=100 \\
C_{2} e^{-A \cdot 60}=50
\end{array}\right\}
$$

egyenletrendszert kapjuk. Az első egyenletből $C_{2}=100$, ezt visszaírva a másodikba, és kifejezve a másik konstanst:

$$
A=\frac{\ln 2}{60} .
$$

Tehát a kezdeti feltételeknek megfelelő partikuláris megoldás

$$
N(t)=100 e^{-\frac{\ln 2}{60} t} .
$$

Ebből kiszámítjuk a radioaktív atommagok számát a bomlási folyamat kezdetétől számított másfél perc, azaz 90 másodperc múlva:

$$
N(90)=100 e^{-\frac{\ln 2}{60} \cdot 90} \approx 35(\mathrm{db}) .
$$

5. A légnyomás a magasság növekedésével csökken. Jelöljük $p(z)$-vel a légnyomásmagasság függvényt. Nagy magasságkülönbségek estén a légnyomás magasságtól való függését a $p^{\prime}(z)=-A p(z)$ differenciálegyenlet írja le (ahol $A \in \mathbb{R}$ ), azonos hőmérsékletü légoszlopot feltételezve. (A Föld légkörének hömérséklete $\mathrm{kb} .11 \mathrm{~km}$ magasságig kilométerenként $k b .6,5^{\circ} \mathrm{C}-k a l$ csökken, így a hömérsékletet tekinthetjük állandónak.) Tudjuk, hogy a légnyomás tengerszinten átlagosan $1013 \mathrm{hPa}$, illetve tengerszint felett 300 méteres magasságban átlagosan $977 \mathrm{hPa}$. Határozzuk meg a légnyomás értékét a tengerszint felett 1000 méteres magasságban!

Megoldás.

A feladatban adott szétválasztható változójú differenciálegyenlet megoldásának menete hasonló az előző feladatban leírtakhoz, így nem részletezzük:

$$
\begin{gathered}
\int \frac{p^{\prime}(z)}{p(z)} d z=\int-A d z, \\
\vdots \\
p(z)=C e^{-A z}, \quad C \in \mathbb{R} .
\end{gathered}
$$


A differenciálegyenlet megoldásául kapott $p(z)$ függvény neve barometrikus magasságformula. A kezdeti feltételek szerint $p(0)=1013$, és $p(300)=977$, ezeket behelyettesítve az általános megoldásba az

$$
\left.\begin{array}{l}
C e^{-A \cdot 0}=1013 \\
C e^{-A \cdot 300}=977
\end{array}\right\}
$$

egyenletrendszert kapjuk. Az első egyenletből $C=1013$, ezt visszaírva a másodikba és a másik konstanst kifejezve:

$$
A=-\frac{1}{300} \ln \frac{977}{1013}
$$

Tehát a kezdeti feltételeknek megfelelő partikuláris megoldás:

$$
p(z)=1013 e^{\frac{z}{300} \ln \frac{977}{1013}}
$$

Ennek segítségével kiszámítjuk az 1000 méter magasságban lévő légnyomás értékét:

$$
p(1000)=1013 e^{\frac{1000}{300} \ln \frac{977}{1013}} \approx 886,37(\mathrm{hPa}) .
$$

Megjegyzés:

A légnyomás értékének becslésekor a Föld felszínének közelében 100 méterenként közelítőleg $1,2 \mathrm{kPa}$ légnyomás csökkenéssel szoktak számolni. Esetünkben ez a becslés $p(1000)=$ $1013-120=893(\mathrm{hPa})$ eredményt adott volna.

6. Egy henger alakú tartályban 1,44 m magasságig víz áll. A tartály alján egy kör alakú lefolyónyílás van dugóval bezárva. Kihúzzuk a dugót. Jelöljük $h(t)$-vel a tartályban lévő vízoszlop magasság-idő függvényét. A vízoszlop magassága minden időpillanatban a pillanatnyi magasság négyzetgyökével arányosan csökken, azaz: $-h^{\prime}(t)=A \cdot \sqrt{h(t)}$, ahol $A \in \mathbb{R}$ arányossági tényezô. $A$ dugó kihúzásától számított 1 perc múlva a víz magassága 1 m. Mennyi idő alatt ürül ki a tartály?

Megoldás.

A differenciálegyenlet változóit szétválasztjuk, az integrálást elvégezzük és az egyenletet $\mathrm{h}(\mathrm{t})$ re rendezzük:

$$
\begin{gathered}
\frac{h^{\prime}(t)}{\sqrt{\mathrm{h}(\mathrm{t})}}=-A, \\
\int \frac{h^{\prime}(t)}{\sqrt{\mathrm{h}(\mathrm{t})}} d t=\int-A d t, \\
2 \sqrt{\mathrm{h}(\mathrm{t})}=-A t+C_{1}, A, C_{1} \in \mathbb{R}, \\
\mathrm{h}(\mathrm{t})=\left(-\frac{A}{2} t+\frac{C_{1}}{2}\right)^{2}=\frac{1}{4}\left(C_{1}-A t\right)^{2} .
\end{gathered}
$$

A kezdeti feltételek szerint $h(0)=1,44$, és $h(1)=1$ (az időt percben mérjük, a magasságot méterben). A megoldás utolsó, explicit alakjában szereplő négyzetre emelés a konstansok meghatározását kicsit bonyolítja. (Az első kezdeti feltételt ebbe visszaírva $C_{1}= \pm 2,4$, a két $C_{1}$ érték mindegyikéhez $A$-ra szintén két-két eredményt kapunk. Természetesen később kiderül, 
hogy melyek azok a konstans értékek, amelyek nem tesznek eleget a követelményeknek.) Ehelyett egyszerübben meg tudjuk határozni a konstansokat a levezetés utolsó előtti sorából, vagyis a differenciálegyenlet általános megoldásának implicit alakjából:

$$
\left.\begin{array}{c}
2 \sqrt{1,44}=-A \cdot 0+C_{1} \\
2 \sqrt{1}=-A \cdot 1+C_{1}
\end{array}\right\}
$$

Az első egyenletből $C_{1}=2,4$, ezt visszaírva a másodikba az $A=0,4$ eredmény adódik. A konstansokat behelyettesítve az általános megoldás explicit alakjába a következő partikuláris megoldást kapjuk:

$$
h_{p}(\mathrm{t})=\frac{1}{4}(2,4-0,4 t)^{2}=(1,2-0,2 t)^{2} .
$$

Ebből meg tudjuk határozni, hogy mennyi idő alatt ürül ki a tartály:

$$
\begin{gathered}
0=(1,2-0,2 t)^{2}, \\
t=6(\text { perc }) .
\end{gathered}
$$

7. Lekvárfözéskor egy üveg lekvár hömérséklete $20^{\circ} \mathrm{C}$-os környezetben 10 perc alatt hül le $100^{\circ} \mathrm{C}$-ról $80^{\circ} \mathrm{C}$-ra. Határozzuk meg a test hömérsékletét a vizsgálat kezdetétől számított 30 perc múlva. Mikor lesz a test hőmérséklete $40^{\circ} \mathrm{C}-o s$ ? Jelöljük $T(t)$-vel a lekvár hömérséklet-idő függvényét. A Newton-féle hülési törvény szerint egy test hőmérsékletének változása egyenesen arányos a test és a környezet hömérsékletének különbségével, azaz: $T^{\prime}(t)=-\lambda\left(T(t)-T_{k}\right)$, ahol $\lambda \in \mathbb{R}^{+}$arányossági tényező a test anyagára és alakjára jellemző pozitív állandó, $T_{k}$ pedig a környezet hömérséklete.

Megoldás.

A feladatban adott differenciálegyenletből indulunk ki, amely szétválasztható változójú:

$$
\begin{gathered}
\frac{T^{\prime}(t)}{T(t)-T_{k}}=-\lambda, \\
\int \frac{T^{\prime}(t)}{T(t)-T_{k}} d t=\int-\lambda d t, \\
\ln \left|T(t)-T_{k}\right|=-\lambda t+C, \quad C \in \mathbb{R}, \\
\left|T(t)-T_{k}\right|=e^{-\lambda t+C}, \\
T(t)-T_{k}= \pm e^{-\lambda t} e^{C} .
\end{gathered}
$$

$\mathrm{A} \pm e^{C}=C_{2}\left(C_{2} \in \mathbb{R}\right)$ konstanst bevezetve:

$$
T(t)=C_{2} e^{-\lambda t}+T_{k}, \quad \lambda \in \mathbb{R}^{+}, C_{2} \in \mathbb{R} .
$$

Az egyenletbe behelyettesítjük a $T_{k}=20$ értéket, vagyis a környezet feladatban adott hőmérsékletét. A függvényben lévő két szabadon választható paraméter ( $\lambda$ és $\left.C_{2}\right)$ értékét a feladat által megadott kezdeti feltételek $(T(0)=100, T(10)=80)$ általános megoldásba történő behelyettesítésével kapjuk meg: 


$$
\left.\begin{array}{l}
100=C_{2} e^{-\lambda \cdot 0}+20 \\
80=C_{2} e^{-\lambda \cdot 10}+20
\end{array}\right\}
$$

Az első egyenletből $C_{2}=80$, ezt visszaírva a másodikba:

$$
\lambda=-\frac{1}{10} \ln \frac{3}{4}
$$

A kezdeti feltételeknek megfelelő konstansok értékeit behelyettesítjük az általános megoldásba, így megkapjuk a partikuláris megoldást, amely megadja a lekvár hömérsékletét az idő függvényében:

$$
T(t)=80 e^{\frac{t}{10} \ln \frac{3}{4}}+20
$$

Ebből kiszámítjuk, hogy hány fokos lesz a lekvár hőmérséklete 30 perc múlva:

$$
T(30)=80 e^{\frac{30}{10} \ln \frac{3}{4}}+20=53,75^{\circ},
$$

illetve azt is, hogy mikor lesz a lekvár hőmérséklete $40^{\circ} \mathrm{C}$-os:

$$
\begin{gathered}
80 e^{\frac{t}{10} \ln \frac{3}{4}}+20=40, \\
e^{\frac{t}{10} \ln \frac{3}{4}}=\frac{1}{4}, \\
t=10 \cdot \frac{\ln \frac{1}{4}}{\ln \frac{3}{4}} \approx 48,19 \text { (perc). }
\end{gathered}
$$

Megjegyzés:

A $\lim _{t \rightarrow \infty} T(t)$ határértéket vizsgálva látható, hogy a lekvár idővel felveszi a környezet hőmérsékletét, azaz a függvény eleget tesz annak, amit a fizikai ismereteink alapján várunk:

$$
\lim _{t \rightarrow \infty}\left(80 e^{\frac{t}{10} \ln \frac{3}{4}}+20\right)=\lim _{t \rightarrow \infty}\left(80 e^{-0,0288 \cdot t}+20\right)=20 .
$$

8. Egy csésze kávéba $10 \mathrm{~g}$ cukrot teszünk. Fél perc múlva már csak $1 \mathrm{~g}$ fel nem oldott cukor van benne. Mennyi lesz a még fel nem oldódott cukor mennyisége 1 perc múlva? Mikor oldódik fel a cukor 99,9\%-a? És az összes cukor? Jelöljük m(t)-vel a még fel nem oldódott cukor tömegét az idő függvényében, továbbá legyen $m_{k}$ a kávéba tett cukor tömege. Az oldódás sebessége arányos a még fel nem oldódott cukor mennyiségével: $m^{\prime}(t)=$ $A\left(m_{k}-m(t)\right)$, ahol $A \in \mathbb{R}$ arányossági tényező.

Megoldás.

A feladatban adott differenciálegyenletből indulunk ki, amely az elöbbihez hasonló szétválasztható változójú differenciálegyenlet. A megoldás lépéseit nem részletezzük: 


$$
\begin{gathered}
\frac{m^{\prime}(t)}{m_{k}-m(t)}=A \\
\vdots \\
m_{k}-m(t)= \pm e^{-A t} e^{-C}, \text { ahol } A, C \in \mathbb{R} .
\end{gathered}
$$

$\mathrm{A} \pm e^{-C}=C_{2}\left(\right.$ ahol $\left.C_{2} \in \mathbb{R}\right)$, illetve a $-A=A_{2}\left(A_{2} \in \mathbb{R}\right)$ konstansokat bevezetve:

$$
m(t)=m_{k}-C_{2} e^{A_{2} t}, \quad A_{2}, C_{2} \in \mathbb{R} .
$$

A kapott függvényben lévő két szabadon választható paraméter $\left(A_{2}\right.$ és $\left.C_{2}\right)$ értékét a kezdeti feltételekkel határozzuk meg. Ezek $m(0)=0$, hiszen a $t=0$ időpillanatban még nincs feloldódott cukor, illetve $m(30)=9$, mert fél perc múlva már $9 \mathrm{~g}$ cukor feloldódott. Behelyettesítjük az egyenletbe az $m_{k}=10$ értéket is, azaz az

$$
\left.\begin{array}{c}
10-C_{2} e^{A_{2} \cdot 0}=0 \\
10-C_{2} e^{A_{2} \cdot 30}=9
\end{array}\right\}
$$

egyenletrendszert kapjuk. Az első egyenletből $C_{2}=10$, ezt visszaírva a másodikba

$$
A_{2}=\frac{1}{30} \ln \frac{1}{10}
$$

adódik. Tehát a kezdeti feltételeknek megfelelő partikuláris megoldás:

$$
m(t)=10-10 e^{\frac{t}{30} \ln \frac{1}{10}}=10\left(1-e^{\frac{t}{30} \ln \frac{1}{10}}\right) .
$$

Ebből kiszámoljuk a 1 perc elteltével feloldódott cukor mennyiségét:

$$
m(60)=10\left(1-e^{\frac{60}{30} \ln \frac{1}{10}}\right) \approx 9,9(g) .
$$

A feladatban azt is kérdeztük, hogy mikor oldódik fel a cukor 99,9\%-a. Ezt a

$$
10\left(1-e^{\frac{t}{30} \ln \frac{1}{10}}\right)=10 \cdot 0,999
$$

egyenlet megoldásával tudjuk meghatározni.

$$
\begin{gathered}
e^{\frac{t}{30} \ln \frac{1}{10}}=0,001, \\
t=30 \frac{\ln 0,001}{\ln \frac{1}{10}}=90(\mathrm{~s}) .
\end{gathered}
$$

Tehát 1,5 perc múlva oldódik fel a cukor 99,9\%-a. És az összes cukor mikor oldódik fel? A

$$
\lim _{t \rightarrow \infty} m(t)=\lim _{t \rightarrow \infty} 10\left(1-e^{\frac{t}{30} \ln \frac{1}{10}}\right)=\lim _{t \rightarrow \infty} 10\left(1-e^{-0,0767 t}\right)=10
$$

határértéket vizsgálva is látható, hogy végtelen sok idő szükséges ahhoz, hogy az összes cukor feloldódjon. Akármennyi (véges) ideig várunk, mindig lesz egy kevés még fel nem oldódott cukor, azonban a mennyisége rövid idő alatt az érzékelhetőség határa alá csökken. 


\section{3. Összefoglalás}

Hallgatóink számára a felsőbb matematikai ismeretek elsajátítása sok esetben nehézségekkel jár. A differenciálegyenletek témaköréböl különösen nehéz megtalálnunk azokat a feladatokat és azt a tárgyalásmódot, amely számukra érthető. Bízunk abban, hogy az előzőekben felsorolt differenciálegyenletes modellekkel sikerül elérnünk a célunkat:

- a gyakorlati alkalmazás kiemelésével a problémakör lényegét és jelentőségét még jobban megvilágítjuk,

- a szétválasztható változójú differenciálegyenletek témakörében fellelhető típusok széles körére találhatók példák közöttük,

- a differenciálegyenletekkel kapcsolatos fogalmakat még jobban elmélyítjük (pl. a megoldás explicit és implicit alakja, általános megoldás, partikuláris megoldás),

- a fizikai, kémiai ismeretek hiánya nem akadályozza a hallgatókat a probléma megoldásában (a differenciálegyenleteket és a szükséges háttérismereteket a feladatok megadják),

- a függvényhatárérték egy-két gyakorlati alkalmazása ezt a témakört is közelebb hozza a hallgatókhoz.

Meggyőződésünk, hogy a matematika tanulása által hallgatóink olyan kompetenciákra tesznek szert, amelyek a munkahelyek világában és a tudományos élet más területein is gondolkodóvá, precízebbé, kreatívabbá, sikeresebbé teszi őket. Hiszen „a matematika hozzászoktatja a szemünket ahhoz, hogy tisztán és világosan lássa az igazságot” (René Descartes).

\section{Irodalomjegyzék}

[1] Budó Ágoston: Kísérleti fizika I-III., Tankönyvkiadó Budapest, 1978.

[2] Geda Gábor: Modellezés és szimuláció az oktatásban,. Educatio Kht., 2011. https://www.tankonyvtar.hu/en/tartalom/tamop425/0038_informatika_Geda_GaborModellezes_es_szimulacio_az_oktatasban/ch04s05.html

[3] Hatvani László - Pintér Lajos: Differenciálegyenletes modellek a középiskolában. Polygon, Szeged, 1997.

[4] Kurics Tamás: Differenciálegyenletek. ELTE Jegyzet, 2011. http://web.cs.elte.hu/ kuricst/bboard/notes/foldtuddiff_ea.pdf

[5] Ponomarjov, K.K.: Differenciálegyenletek felállítása és megoldása. Tankönyvkiadó, Budapest, 1969.

[6] Scharnitzky Viktor: Differenciálegyenletek. Müszaki Könyvkiadó, Budapest, 2002.

[7] Szaszkó-Bogár Viktor: Közönséges differenciálegyenletek http://www.staff.u-szeged.hu/ vszaszko/ODE\%2020130902.pdf

[8] Terjéki József: Differenciálegyenletek. Polygon, Szeged, 1997. 